\title{
Role of Chitosan in Disease Suppression, Growth and Yield of Carrot
}

\author{
M. A. Rahman, R. Jannat, A. M. Akanda, M. A. R. Khan, and M. T. Rubayet
}

\section{ABSTRACT}

\begin{abstract}
An attempt was made for controlling of Rhizoctonia canker caused by Rhizoctonia solani and southern blight caused by Sclerotium rolfsii in pot and field experiments under inoculated condition and also to increase the growth promoting factors and yield of carrot through the application of chitosan. Before setting the experiments in the field, laboratory experiments were carried out to select virulent isolates of $R$. solani and $S$. rolfsii and effective dose of chitosan on mycelial growth inhibition of virulent isolates of test pathogens. In the pathogenicity test, $R$. solani isolate R-1 and $S$. rolfsii isolate $S-1$ were found to be the most virulent against carrot seedlings. In vitro application of $1.0 \%$ chitosan was found to inhibit $100 \%$ mycelial growth of both tested pathogens. The field experiment was laid out following randomized complete block design with four treatments, where no treatment was done in $T_{1}$, pathogen was inoculated in $T_{2}$ and seed treatment and soil amendment with $1.0 \%$ chitosan was done in $T_{3}$ and $T_{4}$, respectively, in pathogen inoculated condition. Application of $1.0 \%$ chitosan as seed treatment or soil amendment significantly reduced postemergence seedling mortality, incidence of diseases and enhanced seedling growth and also yields of carrot. On the contrary, post-emergence seedling mortality, incidence of Rhizoctonia canker and southern blight of carrot were highest in treatment $T_{2}$ where soil was inoculated with pathogens. Chitosan could be used as an alternative of fungicide to suppress Rhizoctonia canker and southern blight in sustainable agriculture and improvement the yield of carrot.
\end{abstract}

Keywords: Chitosan, Rhizoctonia root rot, Southern blight, Growth, and Yield.
Submitted : March 18, 2021

Published : May 10, 2021

ISSN: $2684-1827$

DOI: $10.24018 /$ ejfood.2021.3.3.266

\section{A. Rahman}

Dept. of Plant Pathology, Bangabandhu Sheikh Mujibur Rahman Agricultural University, Gazipur-1706, Bangladesh. R. Jannat*

Dept. of Plant Pathology, Bangabandhu Sheikh Mujibur Rahman Agricultural University, Gazipur-1706, Bangladesh.

(e-mail: rjannat ${ }^{@ b s m r a u . e d u . b d) ~}$

A. M. Akanda

UGC Professor, Dept. of Plant Pathology, Bangabandhu Sheikh Mujibur Rahman Agricultural University, Gazipur-1706, Bangladesh.

M. A. R. Khan

Dept. of Agronomy, Bangabandhu Sheikh Mujibur Rahman Agricultural University, Gazipur-1706, Bangladesh.

M. T. Rubayet

Dept. of Plant Pathology, Bangabandhu Sheikh Mujibur Rahman Agricultural University, Gazipur-1706, Bangladesh.

*Corresponding Author

\section{INTRODUCTION}

Carrot (Daucus carrota L.) belongs to the family Apiaceae and grown all over the world in spring, summer and autumn in temperate and during winter under tropical and subtropical regions. In Bangladesh mid-November to early December (rabi season) is the best time for its cultivation [1]. Carrot roots are valued as food mainly for its high carotene content. Additionally, it is an excellent source of iron and contains good qualities of vitamin $\mathrm{B}$ and $\mathrm{C}$ and rich in sugar [2].

However, there are several factors ascribed for the low production of carrot such as climatic conditions, variation in rainfall pattern, and an out-break of diseases and pests. Among these factors, plant diseases play a major role in yield reduction of carrot. The most important diseases of carrot roots are Rhizoctonia crown rot and canker, southern blight, Pythium rot, cottony rot, black rot, scab, bacterial soft rot, etc. But information regarding diseases of carrot and their management is very scarce in Bangladesh.

Rhizoctonia fungus which causes damping off when seedlings are small. On carrot roots, early symptoms are horizontal dark brown lesions; as the crop matures the tops may die in patches in the field. Pre-and post-emergence damping off were observed in the greenhouse for approximately 30 days after planting. Crown rot symptoms were predominant in inoculated plants at 30-60 days after seeding and in naturally infected plants of similar age in the field. Rhizoctonia canker was the predominant symptom in infected plant 60 or more days old. The incidence and severity of canker increased through the growing season. Rhizoctonia crown rot and canker can severely downgrade carrot pack out and profitability.

On the other hand, infection of $S$. rolfsii usually begins at or near the soil surface. Rotting begins at the top of the taproot and the base of the leaf petioles. Leaf tissues turn brown and may wilt. A white mycelial growth may appear on the soil surface. As the root rot progresses downward, small spherical tan fungal bodies called sclerotia may develop within the rotted root tissues. Moreover, $S$. rolfsii reduces the crop stand by causing pre- and post-emergence damping off of seedlings. Contamination of carrot root with $S$. rolfsii in the field lead to the development of rot in the storage and during conveyance. 
Despite the importance of these pathogens in carrot fields, limited information has been available on the disease epidemiology and control. Currently, there is no effective control strategy for the control of serious diseases of carrot. Control of soil borne diseases especially caused by Rhizoctonia and Sclerotium are nearly impossible if crop is grown under wet condition. Planting on ridges, crop rotation, careful handling during harvest, storage sanitation and extremely good storage conditions might reduce losses to the disease. Seed treatment with fungicide reduces damping off and seedling mortality caused by soil borne fungal pathogens. Indiscriminate use of chemical pesticides and fertilizers in modern agriculture has resulted in the development of several problems such as pesticide resistance in pests, resurgence of target and non-target pests, destruction of beneficial organisms and chemical residues in food, feed and fodder.

Considering the deleterious effect of synthetic pesticides on life supporting system, there is an urgent need for alternative agents for the control of pathogenic microorganisms. Therefore, in the absence of resistant cultivars, bio-pesticides, such as chitosan offer a more sustainable approach for the control of diseases in fruits and vegetables [3], [4]. Chitosan is a linear polysaccharide composed of randomly distributed $-\beta-(1 \rightarrow 4)$-linked Dglucosamine (deacetylated unit). It is made by treating the chitin shells of shrimp and other crustaceans with an alkaline substance, like sodium hydroxide. It is considered as a biodegradable and biocompatible material with no toxicity or side effects [5]. Over the last decade, chitosan polysaccharide has taken on enormous importance in the control of pathogenic microorganisms. The presence of amino groups ($\mathrm{NH}_{2}$ ) in its chemical structure gives chitosan unique and ideal food conservation and security properties which are exploited through the development of biodegradable edible coatings and films containing natural antimicrobials; it also has elicitor properties that enhance the natural defenses of fruit, vegetables and grains [6]. Vasudevan et al. [7] suggested that application of chitosan formulation can increase root and shoot length and grain yield. It also increases the growth of nursery-raised plants such as cucumber, pepper and tomato etc. Defense mechanism in plant has been accelerated by using chitosan. Ortega-Ortiz et al. [8] reported that chitosan could increase catalase (CAT) and peroxidase (POD) enzymes activity in Lycopersicon esculentum. Therefore, the research aim is to evaluate the effect of chitosan in controlling the diseases and progress growth and yield of carrot.

\section{MATERIALS AND METHODS}

\section{A. Experimental Site}

A field experiment was carried out at Bangabandhu Sheikh Mujibur Rahman Agricultural University from 2018 to 2019. Geographically the experimental area is located at $24^{\circ} 09^{\prime} \mathrm{N}$ latitude and $90^{\circ} 26^{\prime}$ longitudes at the elevation of $8.2 \mathrm{~m}$ from sea level [9], [10]. The soil type of the experimental site belongs to the shallow red-brown terrace type under Salna series of Madhupur tract of Agroecological zone (AEZ) 28 which is characterized by silty clay with a $\mathrm{pH}$ value of 6.5 . The experimental site is under the subtropical climatic zone which is characterized by less rainfall, almost clear sunshine and moderate temperature. The average temperature and annual rainfall in Gazipur are $25.8{ }^{\circ} \mathrm{C}$ and $2036 \mathrm{~mm}$, respectively.

\section{B. Experimental Materials}

Seeds sample of carrot variety "New Kuroda" was collected from the Lal teer seed limited, Dhaka, Bangladesh.

\section{Collection, Isolation, and Preservation of R. solani and} S. rolfsii

Three individual isolates of $R$. solani and $S$. rolfsii were collected from the infected tomato, carrot, and potato fields at BSMRAU, Gazipur, Bangladesh. The specimens which had typical symptoms of root rot and blight were selected from the infected fields. The fungal isolates were isolated according to standard method [11]. Then, the fungal colonies were grown on PDA and identified according to Barnet and Hunter [12]. Finally, the isolates were purified following hyphal tip technique and stored in PDA slants at $10^{\circ} \mathrm{C}$.

\section{Pathogenicity Test for the Selection of Virulent Isolates of the Test Pathogens in Pot Culture}

The pathogenicity test of $R$. solani and $S$. rolfsii isolates were conducted in pot culture on carrot seedling according to the Akter et al. [3], Rubayet et al. [13], Liton et al. [14].

\section{E. Inoculum Preparation of the Test Pathogens}

Inocula of the $R$. solani and $S$. rolfsii isolates were prepared and stored according to the standard method [15].

\section{F. Collection and Preservation of Chitosan}

Chitosan was collected from Sisco Research Laboratories Pvt. Ltd. (SRL), India. It was derived from the cell of quick growing sea shrimp. The solution was extracted from sea shrimp and then it was irradiated with $\gamma$-ray (20 KD) which acts as a plant growth promoter.

\section{G. In vitro Screening of Chitosan}

Different concentrations of chitosan such as $0.6,0.8$, and $1.0 \%$ were evaluated on PDA plate against $R$. solani and $S$. rolfsii following the methods of Akter et al. [3], Jannat et al. [4]. Finally, the percent inhibition of the radial growth was calculated as described by the formula as given below:

$$
\% \text { inhibition of growth }=\frac{X-Y}{X} \times 100
$$

where, $\mathrm{X}=$ Mycelial growth of pathogen without chitosan (control), and $\mathrm{Y}=$ Mycelial growth of pathogen with chitosan (R. solani and $S$. rolfsii).

\section{H. Treatments}

Two field experiments were laid out for $R$. solani and $S$. rolfsii separately with the following treatments:

$\mathrm{T}_{1}=$ Control;

$\mathrm{T}_{2}=$ Soil inoculated with pathogen $(S$. rolfsii/ $R$. solani $) ;$ $\mathrm{T}_{3}=$ Soil inoculated with pathogen $(S$. rolfsii/ $R$. solani); and seed treated with $1.0 \%$ chitosan;

$\mathrm{T}_{4}=$ Soil inoculated with pathogen $(S$. rolfsii/ $R$. solani $) ;$ and amendment with $1.0 \%$ chitosan.

\section{Land Preparation and Design of Experiment}

Land was prepared for well tilth using a tractor driven disc plough, rotavator and harrow. The experiment was laid out in 
the Randomized Complete Block Design (RCBD) with three replications. After land preparation the whole experimental area was divided into three blocks, which represent three replications. The unit plot size was $2.0 \mathrm{~m} \times 2.0 \mathrm{~m}$. Distance between block to block was $1.0 \mathrm{~m}$ and that of plot to plot in a block was $0.5 \mathrm{~m}$. Drains were made surrounding each unit plots and the excavated soil was used for raising plots $15 \mathrm{~cm}$ high from the general soil surface. Four different treatments were allotted randomly to four-unit plots per block.

\section{J. Use of Manure and Fertilizer}

Well decomposed cow dung @ 5 t/ha was applied during the land preparation. For medium soil NPKS applied @ 6020-45-12 kg per hectare, respectively. All fertilizer except urea was applied two splits at $3^{\text {rd }}$ and $5^{\text {th }}$ weeks after sowing. Top dressing of fertilizer was followed by irrigation.

\section{K. Seed Treatment and Soil Amendment}

Before sowing, seeds were treated with $1.0 \%$ chitosan for $12 \mathrm{~h}$ as per the required treatment. Seeds were air dried before sowing to avoid excess water. Soil was amended with $1.0 \%$ chitosan just 7 days before of seed sowing.

\section{Sowing of Seeds in Field}

Seeds were sown in the field on 17 November, 2018. Seeds were sown in lines uniformly by hand at the rate of $4.0 \mathrm{~kg} / \mathrm{ha}$ keeping the row-to-row distance of $25 \mathrm{~cm}$. Sowing of seeds were done in rows at a depth of one centimeter for easy emergence and covered with pulverized soil just after sowing and gently pressed with hands. Two hundred seeds were required for one square meter area. After sowing, the soil was mulched with rice straw for preservation of moisture and to facilitate germination. Mulches were removed after 6 days when seeds were started to germinate.

\section{Intercultural Operations}

Weeding, mulching and gap filling were done 3 times up to 45 days of sowing to keep the crop free from weeds and to pulverized the soil crust for better aeration and conserve soil moisture. Seedlings were thinned in continuous row maintaining about $7.0 \mathrm{~cm}$ plant to plant spacing. Light irrigation was provided over the plant at an interval of 14 days (after every alternate week) with the hose pipe until the soil was properly wet.

\section{N. Data Collection}

Data on the \% seedling mortality, $\%$ disease incidence, $\%$ disease severity, root and shoot length $(\mathrm{cm})$, fresh and dry weight $(\mathrm{g})$, root diameter $(\mathrm{cm})$, root weight/ plant $(\mathrm{g})$, yield (t/ha) were collected.

\section{O. Observation of Disease Development}

Germination and seedling disease development were observed regularly and seedling growth recorded at 10, 20 and 30 days after sowing to estimate the effect of chitosan on pre- and post-emergence seedling mortality and growth of carrot. The causal agent of Rhizoctonia root rot and southern blight were confirmed after re-isolation of the pathogens from the ungerminated seeds and diseased seedlings. Rhizoctonia root rot and southern blight disease incidence at different growth stages were recorded. Disease severity of Rhizoctonia root rot was appraised by indexing on five degrees of rating scale in which $0=$ no symptoms, $1=1-25 \%, 2=26-50 \%, 3=$
$51-75 \%$, and $4=76-100 \%$ of carrot root covered with lesions. For, southern blight, severity was assessed based on the rating scale $0-5$, where $0=$ no visible sign or symptoms, $1=$ less than $15 \%, 2=15-35 \%, 3=36-49 \%, 4=50-74 \%$ and $5=$ more than $75 \%$ of carrot rot circumference covered with lesion or mycelium.

\section{P. Disease Assessment}

Disease incidence and percent disease index (PDI) were assessed by the following formula.

$$
\begin{aligned}
& (\%) \text { DI }=\frac{\text { Number of infected plants }}{\text { Total number of plants observed }} \times 100 \\
& \text { PDI }=\frac{\Sigma \text { of rating of plants observed }}{\text { No. of plants observed } \times \text { Max. score of the scale used }} \times 100
\end{aligned}
$$

Percent disease control (PDC) was calculated by the following formula:

$$
\mathrm{PDC}=\frac{(\% \text { disease in check })-(\% \text { disease in treatment })}{(\% \text { disease in check })} \times 100
$$

\section{Q. Harvesting}

Harvesting was done on $18^{\text {th }}$ March 2019 that was three months after sowing. By this time, all the tap roots reached at their desired size and shape. After harvesting weight and diameter of the tap roots were recorded.

\section{R. Statistical Analysis}

Data recorded on diseases and yield component parameters and transformed whenever necessary. Finally, data were analyzed using the Statistix 10 statistical computer program. The means were compared following LSD (Least Significant Difference) test.

\section{RESUlTS AND DISCUSSION}

\section{A. Pathogenicity Test of R. solani and S. rolfsii Isolates against Carrot Seedlings in Pot Culture}

The pathogenicity test of the three selected isolates of $R$. solani and $S$. rolfsii against carrot seedlings were conducted in pot containing sterilized soil to find out most virulent isolates of the test pathogens. All the isolates of the test pathogens were virulent but variable in causing total seedling mortality of carrot (Table I and Fig. 1). The isolate R1 and S1 were appeared to be the most virulent causing the highest $88.34 \%$ and $92.47 \%$ total seedling mortality followed by isolate R2 and S2 caused $75.23 \%$ and $71.14 \%$ mortality in $R$. solani and $S$. rolfsii, respectively. In $R$. solani significantly the lowest $(57.94 \%)$ total seedling mortality was observed with the isolate R3 and in $S$. rolfsii significantly the lowest $(56.71 \%)$ total seedling mortality was observed with the isolate S3. No pre-emergence and post-emergence seedling mortality was observed in the untreated control pot. All the three isolates of each pathogen were able to develop characteristics symptom of Rhizoctonia crown rot and canker and southern blight in carrot seedlings. The variability of these test pathogens were also found by several investigators in different crops [16]-[19]. 
TABLE I. PATHOGENICITY TEST OF $R$. SOLANI AND $S$. ROLFSII ISOLATES AGAinst CARROT SEEDLINGS IN POT CULTURE

\begin{tabular}{|c|c|c|c|}
\hline \multirow[b]{2}{*}{ Isolates } & \multicolumn{3}{|c|}{ Mortality (\%) } \\
\hline & $\begin{array}{c}\text { Pre- } \\
\text { emergence }\end{array}$ & Post-emergence & Total \\
\hline & \multicolumn{3}{|c|}{ R. solani } \\
\hline R1 & $54.34 \mathrm{a}$ & $34.00 \mathrm{a}$ & $88.34 \mathrm{a}^{*}$ \\
\hline $\mathrm{R} 2$ & $44.83 \mathrm{~b}$ & $30.40 \mathrm{~b}$ & $75.23 \mathrm{~b}$ \\
\hline R3 & $34.14 \mathrm{c}$ & $23.80 \mathrm{c}$ & $57.94 \mathrm{c}$ \\
\hline Untreated control & $0.00 \mathrm{~d}$ & $0.00 \mathrm{~d}$ & $0.00 \mathrm{~d}$ \\
\hline \multicolumn{4}{|c|}{ S. rolfsii } \\
\hline S1 & $65.67 \mathrm{a}$ & $26.80 \mathrm{a}$ & $92.47 \mathrm{a}$ \\
\hline $\mathrm{S} 2$ & $54.27 \mathrm{~b}$ & $16.87 \mathrm{c}$ & $71.14 \mathrm{~b}$ \\
\hline S3 & $33.06 \mathrm{c}$ & $23.65 \mathrm{~b}$ & $56.71 \mathrm{c}$ \\
\hline Untreated control & $0.00 \mathrm{~d}$ & $0.00 \mathrm{~d}$ & $0.00 \mathrm{~d}$ \\
\hline
\end{tabular}

*Means within the same column having a common letter (s) do not differ significantly $(P=0.05)$ by LSD.
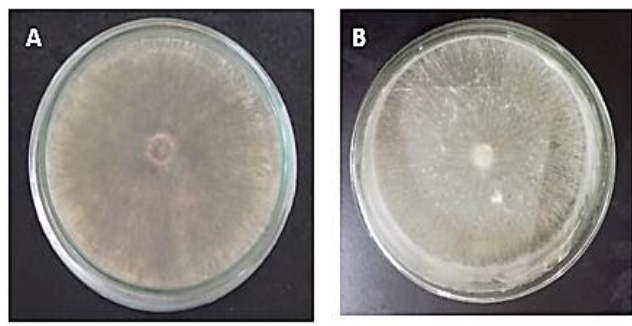

Fig. 1. Virulent isolates of $R$. solani (A) and S. rolfsii (B).

\section{B. Effect of Chitosan on Mycelial Growth of Virulent Isolates of $R$. solani and $S$. rolfsii}

The mycelial growth of the test pathogens was significantly reduced with all the three used concentrations viz., $0.6,0.8$, and $1.0 \%$ of chitosan as compared to untreated control (Table II). All the three concentrations of chitosan were significantly variable in reducing the mycelial growth of $R$. solani and S. rolfsii. Significantly the highest $100 \%$ reduction of the mycelial growth of $R$. solani and $S$. rolfsii over the control PDA plate were observed at $1.0 \%$ of chitosan amended with PDA plate followed by the second highest $0.8 \%$ of chitosan with $77.09 \%$ and $67.50 \%$ reduction of mycelial growth, respectively. Significantly the lowest $70.41 \%$ and $61.67 \%$ reduction of the mycelial growth of $R$. solani and $S$. rolfsii, respectively were observed at the lowest $0.6 \%$ concentration of chitosan amended with the PDA plate. Based on the in vitro evaluation the most effective $1.0 \%$ chitosan concentration was selected for the field trial. The similar results found by the reports of Akter et al. [3], Silva et al. [20], Sunpapao et al. [21].

TABLE II: MYCELIAL GROWTH INHIBITION OF R. SOLANI AND S. ROLFSII BY CHITOSAN ON PDA

\begin{tabular}{ccccc}
\hline \multirow{2}{*}{ Treatments } & \multicolumn{2}{c}{$\begin{array}{c}\text { Mycelial growth (mm) } \\
\text { after 7 days of incubation }\end{array}$} & \multicolumn{2}{c}{$\begin{array}{c}\text { \% mycelial growth } \\
\text { inhibition over control }\end{array}$} \\
\cline { 2 - 5 } & R. solani & S. rolfsii & R. solani & S. rolfsii \\
\hline $\begin{array}{c}\text { Control (no } \\
\text { chitosan) } \\
0.6 \%\end{array}$ & $79.20 \mathrm{a}$ & $80.00 \mathrm{a}^{*}$ & - & - \\
$\begin{array}{c}\text { chitosan } \\
0.8 \%\end{array}$ & $25.12 \mathrm{~b}$ & $30.67 \mathrm{~b}$ & 70.41 & 61.67 \\
$\begin{array}{c}\text { chitosan } \\
1.0 \%\end{array}$ & $20.10 \mathrm{c}$ & $25.96 \mathrm{c}$ & 77.09 & 67.50 \\
chitosan & $0.00 \mathrm{~d}$ & $0.00 \mathrm{~d}$ & 100.00 & 100.00
\end{tabular}

*Means within the same column having a common letter (s) do not differ significantly $(P=0.05)$ by LSD.

\section{Effect of Chitosan on Germination and Post-emergence Seedling Mortality}

In addition, to know the effect of chitosan on germination and post-emergence seedling mortality seed treatment and soil amendment were done with $1.0 \%$ of chitosan and there was no chitosan in untreated control seeds. These seeds were sown in plastic tray after required treatments and data were recorded up to complete germination. All treatments increased the germination percentage compared to the treatment where soil was inoculated with the pathogens (Table III). In case of $R$. solani inoculated condition, the range of germination percentage was $50.42-71.71 \%$. The highest germination $71.71 \%$ was in the $\mathrm{T}_{4}$ treatment where soil amendment was done with $1.0 \%$ chitosan followed by $\mathrm{T}_{3}$ treatment where seed treatment was done with $1.0 \%$ chitosan and significantly the lowest germination percentage $50.42 \%$ was in the $\mathrm{T}_{2}$ treatment where soil was inoculated with $R$. solani without chitosan. In case of $S$. rolfsii, the range of germination percentage was $52.47-71.83 \%$. The highest germination $71.83 \%$ was in the $\mathrm{T}_{4}$ treatment where soil amendment was done with $1.0 \%$ chitosan followed by $\mathrm{T}_{3}$ treatment where seed treatment was done with $1.0 \%$ chitosan and significantly the lowest germination percentage $52.47 \%$ was in the $\mathrm{T}_{2}$ treatment where soil was inoculated with $S$. rolfsii without chitosan. The highest germination increased $42.23 \%$ and $36.90 \%$ over pathogen inoculation in $R$. solani and $S$. rolfsii were recorded in the $\mathrm{T}_{4}$ treatment followed by $\mathrm{T}_{3}$ treatment, respectively. In case of seedling mortality, application of chitosan as seed treatment or soil amendment reduced post-emergence seedling mortality compared to the treatment $\mathrm{T}_{2}$ where soil was inoculated with the pathogens. The highest reduction of post emergence seedling mortality $68.20 \%$ and $50.06 \%$ over pathogen inoculation $\left(\mathrm{T}_{2}\right)$ were recorded in $\mathrm{T}_{3}$ treatment where seed treatment was done with $1.0 \%$ chitosan in $R$. solani and $S$. rolfsii, respectively followed by $\mathrm{T}_{4}$ treatment where soil amendment was done with $1.0 \%$ chitosan. This experiment showed that chitosan was effective to increase germination and to control postemergence seedling mortality of carrot.

Seed priming with chitosan improved the germination of ajowan under salt stress [22]. It is well known that chitosan application is beneficial in order to enhance the germination and decrease seedling mortality of many crops [4], [23].

TABLE III: EFFECT OF CHITOSAN ON GERMINATION PERCENTAGE AND Post-EMERGENCE SEEDLING MORTALITY IN $R$. SOLANI AND S. ROLFSII INOCULATED CONDITION

\begin{tabular}{ccccc}
\hline & \multicolumn{4}{c}{ Percentage } \\
\cline { 2 - 5 } Treatments & germination & $\begin{array}{c}\text { increase } \\
\text { over } \mathrm{T}_{2}\end{array}$ & $\begin{array}{c}\text { post- } \\
\text { emergence } \\
\text { mortality }\end{array}$ & $\begin{array}{c}\text { reduction } \\
\text { over } \mathrm{T}_{2}\end{array}$ \\
\hline \multicolumn{5}{c}{ R. solani } \\
\hline $\mathrm{T}_{1}$ & $69.62 \mathrm{ab}$ & - & $5.79 \mathrm{ab}$ & - \\
$\mathrm{T}_{2}$ & $50.42 \mathrm{c}$ & - & $9.78 \mathrm{a}$ & - \\
$\mathrm{T}_{3}$ & $66.17 \mathrm{~b}$ & 31.24 & $3.11 \mathrm{~b}$ & 68.20 \\
$\mathrm{~T}_{4}$ & $71.71 \mathrm{ab}$ & 42.23 & $4.44 \mathrm{~b}$ & 54.60 \\
\hline \multicolumn{5}{c}{ S. rolfsii } \\
$\mathrm{T}_{1}$ & $71.97 \mathrm{a}$ & - & $4.89 \mathrm{~b}$ & - \\
$\mathrm{T}_{2}$ & $52.47 \mathrm{c}$ & - & $8.89 \mathrm{a}$ & - \\
$\mathrm{T}_{3}$ & $61.20 \mathrm{~b}$ & 16.63 & $4.44 \mathrm{~b}$ & 50.06 \\
$\mathrm{~T}_{4}$ & $71.83 \mathrm{a}$ & 36.90 & $4.88 \mathrm{~b}$ & 45.11 \\
\hline
\end{tabular}

*Means within the same column having a common letter (s) do not differ significantly $(P=0.05)$ by LSD. Note: $\mathrm{T}_{1}=$ Seed without any treatment (control), $\mathrm{T}_{2}=$ Soil inoculation with pathogen, $\mathrm{T}_{3}=\mathrm{T}_{2}+$ seed treatment with $1.0 \%$ chitosan, $\mathrm{T}_{4}=\mathrm{T}_{2}+$ soil amendment with $1.0 \%$ chitosan. 


\section{Effect of Chitosan on Growth of Carrot Seedling at} Different Days after Sowing (DAS)

To know the effect of chitosan on growth different related parameters such as shoot length, root length, fresh weight, and dry weight were measured at 30, 40, and 50 DAS, respectively of carrot seedlings in pathogens inoculated condition. Chitosan as seed treatment or soil amendment increased growth of carrot seedlings at 30, 40, and 50 DAS, respectively (Table IV and Fig. 2).

By the application of chitosan, growth promoting characters were significantly increased in all the treatments over the treatment $\mathrm{T}_{2}$ where soil was inoculated with $R$. solani and $S$. rolfsii. Thirty days after sowing, the highest root length $(3.69 \mathrm{~cm})$, shoot length $(5.20 \mathrm{~cm})$, fresh weight $(0.48 \mathrm{~g})$ and dry weight $(0.09 \mathrm{~g})$ were recorded in $\mathrm{T}_{4}$ treatment where soil amendment was done with $1.0 \%$ chitosan in $R$. solani inoculated condition followed by $\mathrm{T}_{3}$ where seed treatment was done with $1.0 \%$ chitosan. In $S$. rolfsii inoculated condition, the highest root length $(2.78 \mathrm{~cm})$, shoot length $(5.21 \mathrm{~cm})$, fresh weight $(0.37 \mathrm{~g})$ and dry weight $(0.065 \mathrm{~g})$ were recorded in $\mathrm{T}_{3}$ treatment where seed treatment was done with $1.0 \%$ chitosan followed by $\mathrm{T}_{4}$ treatment where soil amendment was done with $1.0 \%$ chitosan. At $40 \mathrm{DAS}$, the highest root length $(7.08 \mathrm{~cm})$, shoot length $(9.73 \mathrm{~cm})$, fresh weight $(3.54 \mathrm{~g})$ and dry weight $(0.62 \mathrm{~g})$ were recorded in $\mathrm{T}_{4}$ treatment where soil amendment was done with $1.0 \%$ chitosan in pathogen inoculated condition followed by $\mathrm{T}_{3}$ where seed treatment was done with $1.0 \%$ chitosan. In case of $S$. rolfsii inoculated condition, the highest root length (6.63 $\mathrm{cm})$, shoot length $(9.94 \mathrm{~cm})$ and fresh weight $(3.18 \mathrm{~g})$ were recorded in $\mathrm{T}_{3}$ treatment where seed treatment was done with $1.0 \%$ chitosan followed by $\mathrm{T}_{4}$ treatment where soil amendment was done with $1.0 \%$ chitosan in pathogen inoculated condition. The highest dry weight $(0.45 \mathrm{~g})$ was recorded in both $\mathrm{T}_{3}$ and $\mathrm{T}_{4}$ treatments.

At 50 DAS, the highest root length $(9.32 \mathrm{~cm})$ and shoot length $(18.45 \mathrm{~cm})$ were recorded in $\mathrm{T}_{3}$ treatment where seed treatment was done with $1.0 \%$ chitosan and highest fresh weight $(13.93 \mathrm{~g})$ and dry weight $(3.86 \mathrm{~g})$ were recorded in $\mathrm{T}_{4}$ treatment where soil amendment was done with $1.0 \%$ chitosan in pathogen inoculated condition. In $S$. rolfsii inoculated condition, the highest root length $(9.33 \mathrm{~cm})$ and dry weight $(3.76 \mathrm{~g})$ were recorded in $\mathrm{T}_{4}$ treatment where soil amendment was done with $1.0 \%$ chitosan and highest shoot length $(16.51 \mathrm{~cm})$ and fresh weight $(16.20 \mathrm{~g})$ were recorded in $\mathrm{T}_{3}$ treatment where seed treatment was done with $1.0 \%$ chitosan. The lowest root length, shoot length, fresh weight and dry weight were recorded in $\mathrm{T}_{2}$ treatment where soil was inoculated with pathogen in both $R$. solani and $S$. rolfsii inoculated fields. There was no statistical difference between the $\mathrm{T}_{3}$ and $\mathrm{T}_{4}$ treatments.

These results confirmed from the findings of Akter et al. [3], and Mondal et al. [24] in which they reported that application of chitosan enhanced seedling growth of different crops. It is also reported that phenolic compounds, flavonoids and antioxidant power increased with increasing concentrations of chitosan as an elicitor [25].
TABLE IV: EFFECT OF CHITOSAN ON GROWTH CHARACTERS OF CARROT AT 30, 40, AND 50 DAS

\begin{tabular}{|c|c|c|c|c|}
\hline Treatments & $\begin{array}{l}\text { Root length } \\
(\mathrm{cm})\end{array}$ & $\begin{array}{c}\text { Shoot } \\
\text { length }(\mathrm{cm})\end{array}$ & $\begin{array}{c}\text { Fresh } \\
\text { weight }(\mathrm{g})\end{array}$ & $\begin{array}{c}\text { Dry weight } \\
(\mathrm{g})\end{array}$ \\
\hline \multicolumn{5}{|c|}{ R. solani } \\
\hline \multicolumn{5}{|c|}{$30 \mathrm{DAS}$} \\
\hline $\mathrm{T}_{1}$ & $3.35 \mathrm{ab}$ & $4.90 \mathrm{a}$ & $0.31 \mathrm{ab}$ & $0.06 \mathrm{bc}^{*}$ \\
\hline $\mathrm{T}_{2}$ & $2.90 \mathrm{~b}$ & $3.84 \mathrm{~b}$ & $0.20 \mathrm{~b}$ & $0.04 \mathrm{c}$ \\
\hline $\mathrm{T}_{3}$ & $3.35 \mathrm{ab}$ & $4.81 \mathrm{a}$ & $0.37 \mathrm{ab}$ & $0.06 \mathrm{bc}$ \\
\hline $\mathrm{T}_{4}$ & $3.69 \mathrm{a}$ & $5.20 \mathrm{a}$ & $0.48 \mathrm{a}$ & $0.09 \mathrm{ab}$ \\
\hline \multicolumn{5}{|c|}{40 DAS } \\
\hline $\mathrm{T}_{1}$ & $6.22 \mathrm{~b}$ & $8.85 \mathrm{ab}$ & $3.30 \mathrm{ab}$ & $0.33 \mathrm{ab}$ \\
\hline $\mathrm{T}_{2}$ & $5.22 \mathrm{c}$ & $6.59 \mathrm{~b}$ & $2.24 \mathrm{~b}$ & $0.23 \mathrm{~b}$ \\
\hline $\mathrm{T}_{3}$ & $6.70 \mathrm{ab}$ & $9.29 \mathrm{a}$ & $3.30 \mathrm{ab}$ & $0.43 \mathrm{ab}$ \\
\hline $\mathrm{T}_{4}$ & $7.08 \mathrm{a}$ & $9.73 \mathrm{a}$ & $3.54 \mathrm{a}$ & $0.58 \mathrm{a}$ \\
\hline \multicolumn{5}{|c|}{$50 \mathrm{DAS}$} \\
\hline $\mathrm{T}_{1}$ & $8.02 \mathrm{a}$ & $18.28 \mathrm{a}$ & $9.90 \mathrm{ab}$ & $2.28 \mathrm{~b}$ \\
\hline $\mathrm{T}_{2}$ & $6.12 \mathrm{~b}$ & $9.53 \mathrm{~b}$ & $4.30 \mathrm{~b}$ & $1.11 \mathrm{c}$ \\
\hline $\mathrm{T}_{3}$ & $9.32 \mathrm{a}$ & $18.45 \mathrm{a}$ & $13.87 \mathrm{a}$ & $3.74 \mathrm{a}$ \\
\hline $\mathrm{T}_{4}$ & $8.98 \mathrm{a}$ & $18.20 \mathrm{a}$ & $13.93 \mathrm{a}$ & $3.86 \mathrm{a}$ \\
\hline \multicolumn{5}{|c|}{ S. rolfsii } \\
\hline \multicolumn{5}{|c|}{$30 \mathrm{DAS}$} \\
\hline $\mathrm{T}_{1}$ & $2.53 \mathrm{ab}$ & $4.54 \mathrm{a}$ & $0.27 \mathrm{~b}$ & $0.047 \mathrm{~b}$ \\
\hline $\mathrm{T}_{2}$ & $2.15 \mathrm{~b}$ & $3.81 \mathrm{~d}$ & $0.17 \mathrm{c}$ & $0.040 \mathrm{~b}$ \\
\hline $\mathrm{T}_{3}$ & $2.78 \mathrm{a}$ & $5.21 \mathrm{ab}$ & $0.37 \mathrm{a}$ & $0.065 \mathrm{a}$ \\
\hline $\mathrm{T}_{4}$ & $2.62 \mathrm{a}$ & $4.71 \mathrm{bc}$ & $0.34 \mathrm{a}$ & $0.057 \mathrm{ab}$ \\
\hline \multicolumn{5}{|c|}{40 DAS } \\
\hline $\mathrm{T}_{1}$ & $6.27 \mathrm{a}$ & $8.67 \mathrm{a}$ & $2.29 \mathrm{ab}$ & $0.31 \mathrm{ab}$ \\
\hline $\mathrm{T}_{2}$ & $4.69 \mathrm{~b}$ & $6.05 \mathrm{~b}$ & $1.52 \mathrm{~b}$ & $0.22 \mathrm{~b}$ \\
\hline $\mathrm{T}_{3}$ & $6.63 \mathrm{a}$ & $9.94 \mathrm{a}$ & $3.18 \mathrm{a}$ & $0.45 \mathrm{a}$ \\
\hline $\mathrm{T}_{4}$ & $6.60 \mathrm{a}$ & $9.39 \mathrm{a}$ & $3.03 \mathrm{a}$ & $0.45 \mathrm{a}$ \\
\hline \multicolumn{5}{|c|}{50 DAS } \\
\hline $\mathrm{T}_{1}$ & $9.43 \mathrm{a}$ & $14.26 \mathrm{~b}$ & $8.97 \mathrm{~b}$ & $2.16 \mathrm{~b}$ \\
\hline $\mathrm{T}_{2}$ & $7.02 \mathrm{~b}$ & $10.53 \mathrm{c}$ & $7.27 \mathrm{~b}$ & $1.47 \mathrm{c}$ \\
\hline $\mathrm{T}_{3}$ & $9.29 \mathrm{a}$ & $16.51 \mathrm{ab}$ & $16.20 \mathrm{a}$ & $3.75 \mathrm{a}$ \\
\hline $\mathrm{T}_{4}$ & $9.33 \mathrm{a}$ & $16.44 \mathrm{ab}$ & $13.81 \mathrm{a}$ & $3.76 \mathrm{a}$ \\
\hline
\end{tabular}

* Means within the same column having a common letter (s) do not differ significantly $(P=0.05)$ by LSD. Note: $\mathrm{T}_{1}=$ Seed without any treatment (control), $\mathrm{T}_{2}=$ Soil inoculation with pathogen, $\mathrm{T}_{3}=\mathrm{T}_{2}+$ seed treatment with $1.0 \%$ chitosan, $\mathrm{T}_{4}=\mathrm{T}_{2}+$ soil amendment with $1.0 \%$ chitosan.
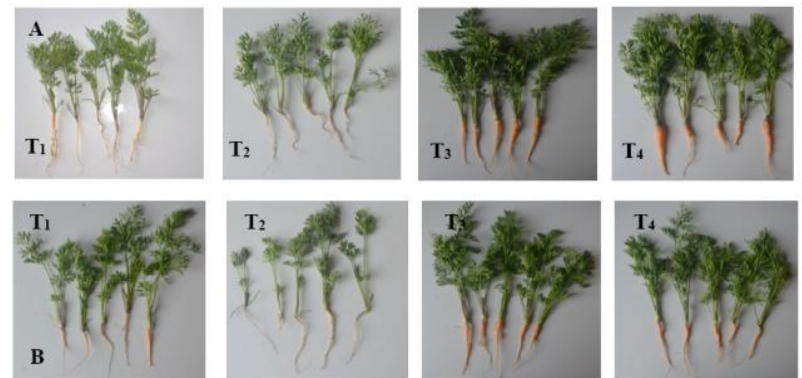

Fig. 2. Effect of chitosan on growth of carrot seedlings in R. solani (A) and $S$. rolfsii $(\mathrm{B})$ inoculated field at $30 \mathrm{DAS}\left(\mathrm{T}_{1}-\mathrm{T}_{4}\right)$.

\section{E. Effect of Chitosan on Rhizoctonia Crown Rot and Canker and Southern Blight Disease Incidence (DI) and Percent Disease Index (PDI)}

Application of chitosan reduced disease incidence (DI) and percent disease index (PDI) in all treatments over pathogens inoculated plots (Table V and Fig. 3). In $R$. solani inoculated field, the highest DI $(36.79 \%)$ and PDI $(27.75 \%)$ at harvest were recorded in the treatment $\mathrm{T}_{2}$ where field was inoculated with pathogen. The lowest DI $(22.37 \%)$ was recorded in $\mathrm{T}_{4}$ treatment where soil amendment was done with $1.0 \%$ chitosan followed by $\mathrm{T}_{3}$ where seed was treated with $1.0 \%$ chitosan and the lowest PDI (16.77\%) was recorded in the treatment $\mathrm{T}_{3}$ where seed was treated with $1.0 \%$ chitosan followed by $\mathrm{T}_{4}$ treatment where soil amendment was done with $1.0 \%$ chitosan. The highest reduction of DI $(39.20 \%)$ was recorded in $\mathrm{T}_{4}$ where soil amendment was done with 
$1.0 \%$ chitosan and the highest reduction of PDI (39.57\%) was recorded in $\mathrm{T}_{3}$ where seed was treated with $1.0 \%$ chitosan over pathogen inoculated plot. In $S$. rolfsii inoculated condition, the highest DI $(24.40 \%)$ and PDI $(17.10 \%)$ at harvest were recorded in the treatment $\mathrm{T}_{2}$ where field was inoculated with $S$. rolfsii. The lowest DI (14.14\%) was recorded in $\mathrm{T}_{3}$ where seed were treated with $1.0 \%$ chitosan followed by $\mathrm{T}_{4}$ treatment where soil amendment was done with $1.0 \%$ chitosan. The lowest PDI $(8.96 \%)$ was recorded in the treatment $\mathrm{T}_{4}$ treatment where soil amendment was done with $1.0 \%$ chitosan followed by $\mathrm{T}_{3}$ where seed was treated with $1.0 \%$ chitosan. The highest reduction of DI $(42.10 \%)$ was recorded in $\mathrm{T}_{3}$ where seed were treated with $1.0 \%$ chitosan over pathogen inoculated plot and the highest reduction of PDI $(47.60 \%)$ was recorded in $\mathrm{T}_{4}$ treatment where soil amendment was done with $1.0 \%$ chitosan over pathogen inoculated plot. No statistical difference was found between $T_{3}$ and $T_{4}$ treatments. Chitosan has antifungal properties and thus may protect plant against fungal pathogens.

Chitosan is often used in plant disease control as a powerful elicitor rather than a direct antimicrobial or toxic agent [26]. Akter et al. [3] and Jannat et al. [4] reported that chitosan effectively reduces DI and PDI of chilli and eggplant. Management of many fungal pathogens in different pathosystems through the application of Trichoderma or chitosan individually or in combination is well documented [27], [28].

TABLE V: EFFECT OF CHITOSAN ON RHIZOCTONIA CANKER AND SOUTHERn BLIGHT DisEASE INCIDENCE (DI) AND PERCENT DisEASE INDEX

\begin{tabular}{|c|c|c|c|c|}
\hline Treatments & $\% \mathrm{DI}$ & $\begin{array}{c}\text { \% reduction } \\
\text { of DI over } \\
\mathrm{T}_{2}\end{array}$ & PDI & $\begin{array}{c}\text { \% reduction } \\
\text { of PDI over } \\
\mathrm{T}_{2}\end{array}$ \\
\hline \multicolumn{5}{|c|}{$R$ solani } \\
\hline $\mathrm{T}_{1}$ & $26.94 \mathrm{~b}$ & - & $16.60 \mathrm{~b}$ & - \\
\hline $\mathrm{T}_{2}$ & $36.79 \mathrm{a}$ & - & $27.75 \mathrm{a}^{*}$ & - \\
\hline $\mathrm{T}_{3}$ & $25.66 \mathrm{bc}$ & 30.25 & $16.77 \mathrm{~b}$ & 39.57 \\
\hline $\mathrm{T}_{4}$ & $22.37 \mathrm{c}$ & 39.20 & $18.10 \mathrm{~b}$ & 34.77 \\
\hline \multicolumn{5}{|c|}{ S. rolfsii } \\
\hline $\mathrm{T}_{1}$ & $17.07 \mathrm{~b}$ & - & $10.52 \mathrm{~b}$ & - \\
\hline $\mathrm{T}_{2}$ & $24.40 \mathrm{a}$ & - & $17.10 \mathrm{a}$ & - \\
\hline $\mathrm{T}_{3}$ & $14.14 \mathrm{bc}$ & 42.10 & $10.97 \mathrm{~b}$ & 35.85 \\
\hline $\mathrm{T}_{4}$ & $17.11 \mathrm{~b}$ & 29.88 & $8.96 \mathrm{~b}$ & 47.60 \\
\hline
\end{tabular}

*Means within the same column having a common letter (s) do not differ significantly $(P=0.05)$ by LSD. Note: $\mathrm{T}_{1}=$ Seed without any treatment (control), $\mathrm{T}_{2}=$ Soil inoculation with pathogen, $\mathrm{T}_{3}=\mathrm{T}_{2}+$ seed treatment with $1.0 \%$ chitosan, $\mathrm{T}_{4}=\mathrm{T}_{2}+$ soil amendment with $1.0 \%$ chitosan.

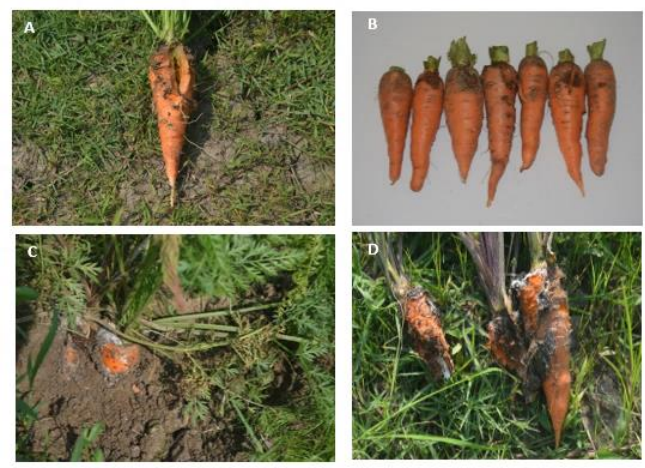

Fig. 3. Rhizoctonia crown rot and canker of carrot caused by $R$. solani (A-B) and southern blight of carrot caused by S. rolfsii (C-D).

\section{F. Effect of Chitosan on the Yield}

By the application of chitosan, yield and yield contributing components were significantly increased in all the treatments over the treatment $T_{2}$ where soil was inoculated with pathogens (Table VI-VII). In $R$. solani inoculated condition, significantly highest yield $(23.17 \mathrm{t} / \mathrm{ha})$, root length $(16.20 \mathrm{~cm})$ and root diameter $(15.10 \mathrm{~cm})$ were recorded in $\mathrm{T}_{3}$ treatment where seed was treated with $1.0 \%$ chitosan followed by $\mathrm{T}_{4}$ treatment where soil amendment was done with $1.0 \%$ chitosan. Significantly lowest yield (12.00 t/ha), root length $(13.44 \mathrm{~cm})$ and root diameter $(10.98 \mathrm{~cm})$ were recorded in $\mathrm{T}_{2}$ Treatment where soil was inoculated with $R$. solani. The highest increase of yield (92.67\%), root length (20.54\%) and diameter $\left(37.52 \%\right.$ ) were observed in $\mathrm{T}_{3}$ followed by $\mathrm{T}_{4}$ over $\mathrm{T}_{2}$.

In $S$. rolfsii inoculated field, the highest yield was (19.91 t/ha) was observed in $\mathrm{T}_{4}$ treatment where soil amendment was done with $1.0 \%$ chitosan and root length $(16.81 \mathrm{~cm})$ and root diameter $(13.55 \mathrm{~cm})$ were recorded in $\mathrm{T}_{3}$ treatment where seed treatment was done with $1.0 \%$ chitosan followed $\mathrm{T}_{4}$ treatment where soil amendment was done with $1.0 \%$ chitosan. Significantly the lowest yield (11.48 t/ha), root length $(14.86 \mathrm{~cm})$ and root diameter $(10.36 \mathrm{~cm})$ were recorded in $\mathrm{T}_{2}$ treatment where soil was inoculated with $S$. rolfsii. Application of chitosan showed the highest increase in root length $(13.12 \%)$ and diameter $(30.79 \%)$ in $\mathrm{T}_{3}$ treatment followed by $\mathrm{T}_{4}$ treatment over $\mathrm{T}_{2}$ treatment and the highest increase yield $(73.43 \%)$ in $\mathrm{T}_{4}$ treatment followed by $\mathrm{T}_{3}$ treatment over $\mathrm{T}_{2}$ treatment. No statistical difference was found between $\mathrm{T}_{3}$ and $\mathrm{T}_{4}$ treatments.

Akter et al. [3], Jannat et al. [4], and Ahmed et al. [29] reported that chitosan significantly increased growth and yield of chilli, eggplant, and carrot.

TABLE VI: EFFECT OF CHITOSAN ON YIELD CONTRIBUTING CHARACTERS

\begin{tabular}{ccccc}
\hline \multicolumn{5}{c}{ OF CARROT } \\
Treatments & $\begin{array}{c}\text { Root length } \\
(\mathrm{cm})\end{array}$ & $\begin{array}{c}\text { \% increase } \\
\text { over } \mathrm{T}_{2}\end{array}$ & $\begin{array}{c}\text { Root } \\
\text { diameter } \\
(\mathrm{cm})\end{array}$ & $\begin{array}{c}\% \\
\text { increase } \\
\text { over } \mathrm{T}_{2}\end{array}$ \\
\hline \multicolumn{5}{c}{ R. solani } \\
\hline $\mathrm{T}_{1}$ & $14.57 \mathrm{~b}$ & - & $12.15 \mathrm{bc}$ & - \\
$\mathrm{T}_{2}$ & $13.44 \mathrm{~b}$ & - & $10.98 \mathrm{c}$ & - \\
$\mathrm{T}_{3}$ & $16.20 \mathrm{a}$ & 20.54 & $15.10 \mathrm{a} *$ & 37.52 \\
$\mathrm{~T}_{4}$ & $16.07 \mathrm{a}$ & 19.57 & $14.36 \mathrm{ab}$ & 30.78 \\
\hline \multicolumn{5}{c}{ S. rolfsii } \\
\hline $\mathrm{T}_{1}$ & $15.69 \mathrm{bc}$ & - & $12.59 \mathrm{c}$ & - \\
$\mathrm{T}_{2}$ & $14.86 \mathrm{c}$ & 13.12 & $13.55 \mathrm{~b}$ & 30.79 \\
$\mathrm{~T}_{3}$ & $16.81 \mathrm{a}$ & $136 \mathrm{~d}$ & 30.41 \\
$\mathrm{~T}_{4}$ & $16.15 \mathrm{ab}$ & 8.68 & $13.51 \mathrm{bc}$ & \\
\hline
\end{tabular}

\begin{tabular}{ccccc}
\multicolumn{5}{c}{ TABLE VII: EFFECT OF CHITOSAN ON YIELD OF CARROT } \\
\hline Treatments & $\begin{array}{c}\text { Weight of } \\
\text { single root }(\mathrm{g})\end{array}$ & $\begin{array}{c}\text { No. of root } \\
\text { per plot }\end{array}$ & $\begin{array}{c}\text { Yield } \\
(\mathrm{t} / \mathrm{ha})\end{array}$ & $\begin{array}{c}\text { \% increase } \\
\text { over } \mathrm{T}_{2}\end{array}$ \\
\hline \multicolumn{5}{c}{ solani } \\
\hline $\mathrm{T}_{1}$ & $113.48 \mathrm{a}$ & $57.33 \mathrm{~b}$ & $21.59 \mathrm{a}^{*}$ & - \\
$\mathrm{T}_{2}$ & $86.38 \mathrm{~b}$ & $41.67 \mathrm{c}$ & $12.05 \mathrm{~b}$ & - \\
$\mathrm{T}_{3}$ & $111.85 \mathrm{a}$ & $62.00 \mathrm{~b}$ & $23.17 \mathrm{a}$ & 92.67 \\
$\mathrm{~T}_{4}$ & $106.92 \mathrm{a}$ & $64.00 \mathrm{~b}$ & $22.81 \mathrm{a}$ & 90.08 \\
\hline \multicolumn{5}{c}{ S. rolfsii } \\
\hline $\mathrm{T}_{1}$ & $102.14 \mathrm{a}$ & $56.67 \mathrm{a}$ & $19.29 \mathrm{a}$ & - \\
$\mathrm{T}_{2}$ & $83.29 \mathrm{c}$ & $41.33 \mathrm{~b}$ & $11.48 \mathrm{~b}$ & - \\
$\mathrm{T}_{3}$ & $95.83 \mathrm{ab}$ & $62.00 \mathrm{a}$ & $19.81 \mathrm{a}$ & 72.56 \\
$\mathrm{~T}_{4}$ & $94.81 \mathrm{~b}$ & $63.00 \mathrm{a}$ & $19.91 \mathrm{a}$ & 73.43 \\
\hline
\end{tabular}

*Means within the same column having a common letter (s) do not differ significantly $(P=0.05)$ by LSD. Note: $\mathrm{T}_{1}=$ Seed without any treatment (control), $\mathrm{T}_{2}=$ Soil inoculation with pathogen, $\mathrm{T}_{3}=\mathrm{T}_{2}+$ seed treatment with $1.0 \%$ chitosan, $\mathrm{T}_{4}=\mathrm{T}_{2}+$ soil amendment with $1.0 \%$ chitosan. 


\section{CONCLUSION}

The study revealed that use of chitosan as seed treatment or soil amendment appeared to be effective in increasing germination percentage, controlling pre- and post-emergence seedling mortality, decreasing disease incidence and severity of Rhizoctonia canker and southern blight with the significant increase of growth and yield of carrot. Farmers may adopt eco-friendly control measures against Rhizoctonia canker and southern blight of carrot through the application of seed treatment by $1.0 \%$ chitosan as an alternative to chemical pesticides.

\section{ACKNOWLEDGMENT}

The authors express their gratefulness to the Ministry of Science and Technology, Dhaka, Bangladesh for providing financial support to accomplish this research work.

\section{CONFLICT OF INTEREST}

Authors declare that there is no conflict of interest.

\section{REFERENCES}

[1] Rashid, M. M. (1999). Shabje Bigjan (in Bengali), $2^{\text {nd }}$ edn. Rashid Publishing House, 94 old D. O. II. S., Dhaka-1206, pp. 498-508.

[2] Uddin, A. S. M. M., Hoque, A. K. M. S., Shahiduzzaman, M., Sarker, P. C., Patwary, M. M. A. \& Shiblee, S. M. A. (2004). Effect of nutrients on the yield of carrot. Pakistan Journal of Biological Sciences, 7(8): 1407-1409.

[3] Akter, J., Jannat, R., Hossain, M. M., Ahmed, J. U. \& Rubayet, M. T. (2018). Chitosan for plant growth promotion and disease suppression against anthracnose in chilli. International Journal of Environment, Agriculture and Biotechnology, 3(3): 806-817.

[4] Jannat, R., Shaha, M., Rubayet, M. T. \& Sultana, S. (2018). Role of chitosan in induction of defense response against Phomopsis vexans and augmentation of growth and yield of eggplant. Global Journal of Science Frontier Research: C Biological Science, 18(3): 6-13.

[5] Rodriguez-Pedroso, A. T., Ramirez-Arrebato, M. A., Rivero-Gonzalez, D., Bosquez-Molina, E., BarreraNecha, L. L. \& Bautista-Banos, S. (2009). Chemical-structural properties and biological activity of chitosan on phytopathogenic microorganisms. Revista Chapingo Serie Horticultura, 15(3): 307-317.

[6] Bautista-Baños, S., Hernandez-Lauzardo, A. N., Velazquez-del Valle, M. G., Hernandez-Lopez, M., Ait, B. E., Bosquez-Molina, E. \& Wilson C. L. (2006). Review: chitosan as a potential natural compound to control pre and postharvest diseases of horticultural commodities. Crop Protection, 25: 108-118.

[7] Vasudevan, P., Reddy, M. S., Kavitha, S., Velusamy, P., PaulRaj, R. S. D., Priyadarisini, V. B., Bharathkumar, S., Kloepper, J. W. \& Gnanamanickam, S. S. (2002). Role of biological preparations in enhancement of rice seedling growth and seed yield. Journal of Agricultural \& Crop Sciences, 83(9): 1140-1143.

[8] Ortega-Ortíz H., Benavides-Mendoza A., Mendoza-Villarreal R., Ramírez-Rodríguez H. \& de Alba-Romenus K. (2007). Enzymatic activity in tomato fruits as a response to chemical elicitors. Journal of the Mexican Chemical Society, 51: 141-144.

[9] Brammer, H. (1971). Soil resources and soil survey project, Bangladesh. AGL: SF/pck.6. Technical Report. Pp 3-8.

[10] Shaheed, S. M. (1984). Soil of Bangladesh: General Soil Types. Soil Resources Development Institute (SRDI) Dhaka, Bangladesh. p.3.

[11] Mian, I. H. (1995). Methods in plant pathology. IPSA-JICA project publication no 24. Institute of Post Graduate Studies in Agriculture. Gazipur1706, Bangladesh.

[12] Barnett, H. L. \& Hunter, B. B. (1972). Illustrated genera of Imperfect fungi. Burges's Publishing Company,. Minneapolis, $241 \mathrm{P}$.

[13] Rubayet, M. T., Bhuiyan, M. K. A. \& Hossain, M. M. (2017). Effect of soil solarization and biofumigation on stem rot disease of potato caused by Sclerotium rolfsii. Annals of Bangladesh Agriculture, 21(1\&2): 4959.
[14] Liton, M. J. A., Bhuiyan, M. K. A., Jannat, R., Ahmed, J. U., Rahman, M. T. \& Rubayet, M. T. (2019). Efficacy of Trichoderma-fortified compost in controlling soil-borne diseases of bush bean (Phaseolus vulgaris $\mathrm{L}$.) and sustainable crop production. Advances in Agricultural Science, 7(2): 123-136.

[15] Rubayet, M. T. \& Bhuiyan, M. K. A. (2016). Integrated management of stem rot of potato caused by Sclerotium rolfsii. Bangladesh Journal of Plant Pathology, 32(1\&2): 7-14.

[16] Punja, Z. K. (1985). The biology, ecology and control of Sclerotium rolfsii. Annual review of Phytopathology, 23: 97-127.

[17] Rubayet, M. T., Bhuiyan, M. K. A., Jannat, R., Masum, M. M. I. \& Hossain, M. M. (2018). Effect of biofumigation and soil solarization on stem canker and black scurf diseases of potato (Solanum tuberosum L.) caused by Rhizoctonia solani isolate PR2. Advances in Agricultural Science, 6(3): 33-48.

[18] Rahman, M. T., Rubayet, M. T. \& Bhuiyan, M. K. A. (2020). Integrated management of rhizoctonia root rot disease of soybean caused by Rhizoctonia solani. Nippon Journal of Environmental Science, 1(7), 1018.

[19] Rubayet, M. T., Prodhan, F., Hossain, M. S., Ahmed, M., Mamun, M. A. A. \& Bhuiyan, M. K. A. (2020). Use of non-chemical methods for the management of southern blight disease of carrot incited by Sclerotium rolfsii. Journal of Agriculture and Applied Biology, 1(2): 74-85.

[20] Silva Jùnior, S., Stamford, N. P., Lima, M. A. B., Arnaud, T. M. S., Pintado, M. \& Sarmento, B. F. (2014). Characterization and inhibitory activity of chitosan on hyphae growth and morphology of Botrytis cinerea plant pathogen. International Journal of Applied Research in Natural Products, 7(4): 31-38.

[21] Sunpapao, A. \& Pornsuriya, C. (2014). Effects of chitosan treatments on para rubber leaf fall disease caused by Phytophthora palmivora Butler-a laboratory study. Songklanakarin Journal of Science \& Technology, 36(5): 507-512.

[22] Mahdavi, B. \& Rahini, A. (2013). Seed priming with chitosan improves the germination and growth performance of ajowan (Carum copticum) under salt stress. Eurasian Journal of Biosciences, 7: 69-76.

[23] Nitu, N. J., Masum, M. M. I., Jannat, R., Sultana S. \& Bhuiyan, M. K. A. (2016). Application of chitosan and Trichoderma against soil-borne pathogens and their effect on yield of tomato (Solanum lycopersicum L.). International Journal of Bio science, 9(1): 10-24.

[24] Mondal, M. M. A., Malek, M. A., Puteh, A. B. \& Ismail, M. R. (2013) Foliar application of chitosan on growth and yield attributes of mung bean [Vigna radiata (L.) Wilczek]. Bangladesh Journal of Botany, 42(1): 179-183.

[25] Salimgandomi, S. \& Shabrangi, A. (2016). The effect of chitosan on antioxidant activity and some secondary metabolites of Mentha piperita L. Journal of Pharmacutical and Health Sciences, 4(2): 135142 .

[26] El-Mohamedy, R. S., Abdel-Kader, M. M., Abd-El-Kareem, F. \& ElMougy, N. S. (2013). Essential oils, inorganic acids and potassium salts as control measures against the growth of tomato root rot pathogens in vitro. Journal of Agricultural Technology, 9(6): 1507-1520.

[27] Nawar, L. S. (2005). Chitosan and three Trichoderma spp. to control Fusarium crown and root rot of tomato in Jeddah, Kingdom Saudi Arabia. Egyptian Journal of Phytopathology, 33: 45-58.

[28] Chittenden, C. \& Singh, T. (2009). In vitro evaluation of combination of Trichoderma harzianum and chitosan for the control of sapstain fungi. Biological control, 50(3): 262-266.

[29] Ahmed, M. U., Bhuiyan, M. K. A., Hossain, M. M., Rubayet, M. T. \& Khaliq, Q. A. (2019). Efficacy of chitosan and bio-agent in controlling southern blight disease of carrot caused by Sclerotium rolfsii and improvement the crop production. Research in Agriculture and Veterinary Science, 3(3): 113-125. 